\title{
Indium In 111 Chimeric Monoclonal Antibody 806
}

National Cancer Institute

\section{Source}

National Cancer Institute. Indium In 111 Chimeric Monoclonal Antibody 806. NCI

Thesaurus. Code C62407.

A recombinant chimeric, mouse-human monoclonal antibody IgG1, directed against the epidermal growth factor receptor (EGFR) and labeled with the radioisotope indium-111, with potential radioimag ing activity. Indium 111 chimeric monoclonal antibody 806 binds to a specific epitope on EGFR-expressing tumor cells, allowing imaging of EGFR-

expressing tumor cells using gamma scintig raphy. EGFR is a receptor tyrosine kinase that is involved in the regulation of cell growth and is found to be overexpressed on the cell surfaces of many tumor cell types. 